\title{
Modifications of Adrenal Gland Ultrastructure in Streptozotocin-Induced Diabetic Model Rats
}

\author{
Modificaciones de la Ultraestructura de la Glándula Suprarrenal \\ en Ratas Modelo Diabéticas Inducidas por Estreptozotocina
}

Sani Baimai; Phrae Bhanichkul; Passara Lanlua; Apichaya Niyomchan \& Sirinush Sricharoenvej

BAIMAI, S.; BHANICHKUL, P.; LANLUA, P.; NIYOMCHAN, A. \& SRICHAROENVEJ, S. Modifications of adrenal gland ultrastructure in streptozotocin-induced diabetic model rats. Int. J. Morphol., 39(1):109-115, 2021.

SUMMARY: The adrenal gland has been associated with the development of classical symptoms in diabetes mellitus (DM), including intensive polyuria and hyperglycemia. During DM, there are hormonal changes in the adrenal gland. Ultrastructural changes of adrenocortical and adrenal medulla cells and their effects on adrenocorticomedullary interaction have not been fully investigated. This study evaluated adrenocortical and adrenal medullary cells and adrenocorticomedullary interactions at ultrastructural levels in a streptozotocin-induced DM model, using transmission electron microscopy. Fifteen male, Sprague-Dawley rats were divided into diabetic model $(n=10)$ and control $(n=5)$ groups. Rats were sacrificed at four weeks after induction. The nuclei of some diabetic cortical cells were found to be irregularly shaped. In the cytoplasm, increased numbers of mitochondria and dilated smooth endoplasmic reticulum were observed. However, lipid droplets decreased in the DM model animals. The filopodia of diabetic cortical cells extended to contact the fenestrated capillary and other cortical cells and losses of gap junctions were also observed. Alterations of diabetic chromaffin cells resulted in similar appearances, consisting of irregularly shaped nuclei, swollen mitochondria, distended rough endoplasmic reticulum, and disrupted chromaffin vesicles. Examining adrenocorticomedullary interactions showed that the diabetic cortical chromaffin cells resembled those in the medulla. In the DM model group, collagen fibril depositions were observed between adrenal cells, especially near cell interactions. The filopodia of diabetic cortical cells were larger than those observed for diabetic adrenocorticomedullary interactions and adrenal cortex. These adrenal gland ultrastructural modifications represent contributions to the basic knowledge necessary for investigations of adrenal gland impairment during the early diagnosis of DM patients.

KEY WORDS: Adrenal gland; Adrenocorticomedullary interactions; Streptozotocin; Diabetes mellitus; Rat.

\section{INTRODUCTION}

The adrenal gland is an essential endocrine gland, composed of three outer layers [zona glomerulosa $(\mathrm{ZG})$, zona fasciculata $(\mathrm{ZF})$, and zona reticularis $(\mathrm{ZR})]$ and the inner medulla. The adrenal cortex produces steroid hormones: mineralocorticoids, glucocorticoids, and androgens. Each hormone exerts effects on metabolism, the stress response, and water and electrolyte homeostasis. Epinephrine or norepinephrine, which is produced in the inner medullary layer, regulates the fight or flight response and reactions to stressful conditions (Kierszenbaum \& Tres, 2016).

Diabetes mellitus (DM) is a chronic metabolic disease that affects several systems, including the nervous, urinary, immune, vascular, and endocrine systems (Lanlua et al., 2007; Sricharoenvej et al., 2009; Niyomchan et al., 2019; Lanlua et al., 2019). The adrenal gland has been associated with the DM symptoms, such as polydipsia, polyphagia, and polyuria (Fauci et al., 2009). Aldosterone is synthesized by the ZG cells in response to angiotensin II (AII) levels or adrenocorticotrophic hormone (ACTH) (Kierszenbaum \& Tres). In a short-term DM model, plasma concentrations of aldosterone and AII were found to be high (Hollenberg et al., 2004). ZF cells synthesize and secrete cortisol, which is involved ingluconeogenesis (Kierszenbaum \& Tres). During hyperglycemia, the hypothalamic-pituitary-adrenal axis hyperfunction was observed, which elevates plasma cortisol and corticosterone levels (Rebuffat et al., 1988). As a result, high blood glucose levels occur. ZR synthesizes androgens (Kierszenbaum \& Tres). In short-term diabetic patients, plasma androgen levels are low (Barrett-Connor, 1992). However, the histopathology of diabetic ZR remains unclear. In the adrenal medulla, the levels of medullary 
catecholamines increase in short-term DM model mice (Carson et al., 1982). Cellular relationships between the adrenal cortex and the medulla have been demonstrated, with cortical hormones stimulating medullary hormonal synthesis and vice versa (Haase et al., 2011).

The adrenal gland plays an important role in the progressive development of DM symptoms (Fauci et al.). Extensive literature exists reporting on the biochemical analysis of adrenal hormones. However, the ultrastructural changes that occur in adrenal cells and the relationships between the adrenal cortex and medulla, especially during short-term DM, have not been well-studied. Therefore, we aimed to investigate changes in the adrenal gland at ultrastructural levels in a short-term, streptozotocin (STZ)induced DM model rat using transmission electron microscopy (TEM). This study contributes significant basic knowledge, which can clarify adrenal gland pathology during the progression of short-term DM.

\section{MATERIALS AND METHOD}

Study design and induction of animal models. Animals were approved by the ethics committee of Siriraj Laboratory Animal Research and Care Center, Mahidol University (COA No. 016/2558). Fifteen adult, male, Sprague-Dawley rats, aged 6-8 weeks and weighing between 200-270 g were used (National Laboratory Animal Center, Mahidol University, Thailand). The protocols were adhered to the Guide for the Care and Use of Laboratory Animals. Rats were nourished and tested (Lanlua et al., 2007; Sricharoenvej et al.; Niyomchan et al.; Lanlua et al., 2019). Then, rats were randomly divided into two groups: STZ-induced DM model $(\mathrm{n}=10)$ and control $(n=5)$ groups. In the diabetic group, each rat was intraperitoneally injected with a single dose of $60 \mathrm{mg} / \mathrm{kg}$ body weight STZ (Acros Organics, Janssen Pharmaceutical, Belgium) in citrate buffer, at $\mathrm{pH} 4.5$. The rats in the control group were injected with the same amount of buffer. Urine glucose levels, body weights, and whole-blood glucose levels were monitored.Urine and whole-blood glucose levels above $500 \mathrm{mg} / \mathrm{dL}$ and $300 \mathrm{mg} /$ $\mathrm{dL}$, respectively, were indicated the complete establishment of DM model. After model induction, rats were sacrificed 4 weeks. Five control and ten DM model ratswere processed for the ultrastructural study. Surgery was performed under halothane anesthesia and every effort was made to minimize suffering.

Tissue preparation for ultrastructural study. After perfusion with $0.1 \mathrm{M}$ phosphate-buffered (PBS) saline, 500 $\mathrm{ml} 2.5 \%$ glutaraldehyde in $0.1 \mathrm{M}$ PBS was injected. The adrenal glands were removed and cut into 5-mm3 cubes. Ultrastructural techniques were applied (Niyomchan et al.; Lanlua et al., 2019). The specimens were serially sectioned (80-85 nm thick), stained with $1 \%$ uranyl acetate and lead citrate. The ultrastructural features of the adrenal glands were observed and photographed under a TEM (JEOL JEM 100S, Japan).

Statistical analysis. The body weights are expressed as the mean \pm standard deviation (SD). The Mann-Whitney U test, in the software program SPSS, version 18.0 (SPSS Inc., Chicago, IL, USA), was used to analyze the significance of differences between independent groups, with a p-value $<0.05$.

\section{RESULTS}

After STZ induction, animals developed type $1 \mathrm{DM}$ within $48 \mathrm{~h}$, with typical DM symptoms, including polyphagia, polydipsia, polyuria, and unexplained weight loss (Table I). The urine and the whole-blood glucose levels of DM model rats were greater than $500 \mathrm{ml} / \mathrm{dL}$ (Table II) and $300 \mathrm{mg} / \mathrm{dL}$ (Table III), respectively.

Table I. Comparisons in the body weights of the control and shortterm DM model groups.

\begin{tabular}{|c|c|c|}
\hline \multirow[t]{2}{*}{ Groups } & \multicolumn{2}{|c|}{$\begin{array}{c}\text { Body weights (g.) } \\
(\text { Mean } \pm \text { SD) }\end{array}$} \\
\hline & Before experiment & Before sacrifice \\
\hline Control $(n=7)$ & $218.89 \pm 4.34$ & $468.09 \pm 7.53$ \\
\hline DM model $(n=7)$ & $219.49 \pm 3.58$ & $222.14 \pm 6.79^{*}$ \\
\hline
\end{tabular}

$*$ p-value $<0.05$ compared to the control group.

Table II. Comparisons in the urine glucose levels of the control and short-term DM model groups.

\begin{tabular}{ccc}
\hline \multirow{2}{*}{ Groups } & \multicolumn{2}{c}{ Urine glucose levels $(\mathrm{mg} / \mathrm{dL})$} \\
& Before experiment & Before sacrifice \\
\hline Control $(\mathrm{n}=7)$ & 0 & 0 \\
DM model $(\mathrm{n}=7)$ & 0 & $>500 \mathrm{a}$ \\
\hline
\end{tabular}

a DM is considered as more than $500 \mathrm{mg} / \mathrm{dL}$ of urine glucose levels.

Table III. The comparisons in the whole blood glucose levels of the control and short-term DM model groups.

\begin{tabular}{lcc}
\hline \multirow{2}{*}{ Groups } & \multicolumn{2}{c}{ Whole blood glucose levels $(\mathrm{mg} / \mathrm{dL})$} \\
& Before experiment & Before sacrifice \\
\hline Control $(\mathrm{n}=7)$ & $86.79 \pm 7.35$ & $121.86 \pm 5.89$ \\
DM model $(\mathrm{n}=7)$ & $88.21 \pm 6.65$ & $564.33 \pm 5.53^{\mathrm{b}}$ \\
\hline
\end{tabular}

b DM is indicated as more than $300 \mathrm{mg} / \mathrm{dL}$ of whole blood glucose levels. 
Ultrastructural study of the adrenal cortex. The control ZG cells contained large spherical nuclei. In the cytoplasm, several mitochondria were identified, with tubular cristae, concentrically arranged around the nucleus. Small amounts of lipid droplets were dispersed throughout the cytoplasm (Fig. 1A). In the short-term DM, increased numbers and sizes of mitochondria were observed. In contrast, the volume of lipid droplets in the cytoplasm decreased. Filopodia, which extended from ZG cells to contact either fenestrated capillaries or other ZG cells, were also observed (Fig. 1B). The control ZF cells contained large, spherical nuclei and round mitochondria with vesicular cristae, and numerous large-sized lipid droplets. The gap junctions between ZF cells could be observed (Figs. 1C,E). The DM nuclei of ZF cells were irregular in shape, with invaginations of the nuclear membrane. The mitochondria increased in number and size, whereas fewer and smaller lipid droplets were observed (Fig. 1D). The presence of rough endoplasmic reticulum (rER) and a dilated smooth endoplasmic reticulum (sER) were shown (Fig. 1D: inset). Collagen fibril depositions were observed between the ZF cells. Numerous filopodia were demonstrated, contacting other ZF cells. Few gap junctions were presented between ZF cells in the DM (Fig. 1F). The control ZR cells contained spherical nuclei and fewer lipid droplets and mitochondria, with tubulovesicular cristae. Lipofuscin granules were demonstrated, which were unique to ZR cells (Fig. 1G). In the DM, some nuclei appeared with irregular shapes and invaginations of the nuclear membrane. Increased numbers of mitochondria and a decrease in the number of lipid droplets were observed. Filopodia, which extended to contact other ZR cells, were revealed. Sparse gap junctions were exhibited (Fig. 1H). Fibroblasts and accumulated collagen fibrils were identified in the wide intercellular spaces (Fig. 1H, inset).

Fig. 1. Transmission electron micrographs of zona glomerulosa cells (ZG) (1A-B), zona fascicula (ZF) (1C-F), and zona reticularis (ZR) $(1 \mathrm{G}-\mathrm{H})$ in the adrenal cortex of control $(1 \mathrm{~A}, 1 \mathrm{C}, 1 \mathrm{E}, 1 \mathrm{G})$ and short-term DM model groups $(1 \mathrm{~B}, 1 \mathrm{D} 1 \mathrm{~F}, 1 \mathrm{H})$. Nucleus $(\mathrm{Nu})$, invaginated nuclear membrane (black arrows), mitochondria (black arrowheads), lipid droplets (LD), smooth endoplasmic reticulum (sER), ribosomes (r), lipofuscin granules (LG), filopodia (F), gap junctions (white arrows), capillary lumens (L), collagen fibrils (C), and fibroblast (Fi).

Ultrastructural study of the adrenal medulla. The control chromaffin cells contained large, round nuclei. The cytoplasm contained numerous membrane-bound granules. Cells storing norepinephrine consisted of large-sized granules, with eccentric electron-dense cores. (Figs. 2A,B). Cells storing epinephrine contained small-sized granules, with concentric less electron-dense cores (Figs. 2C,D). Mitochondria, appearing as elongated shapes, well-developed rER and Golgi apparatus structures could be observed (Figs. 2A,C,D). Both types of chromaffin cells displayed similar deteriorating structures in the DM. Irregular nuclei with invaginated nuclear membranes and thick heterochromatin, were observed (Fig. 2D). The disruption of chromaffin vesicles, the loss of cell organelles, swollen and deteriorating mitochondria with disrupted cristae, and distended rER with ruptured features were demonstrated (Figs. 2B,F).
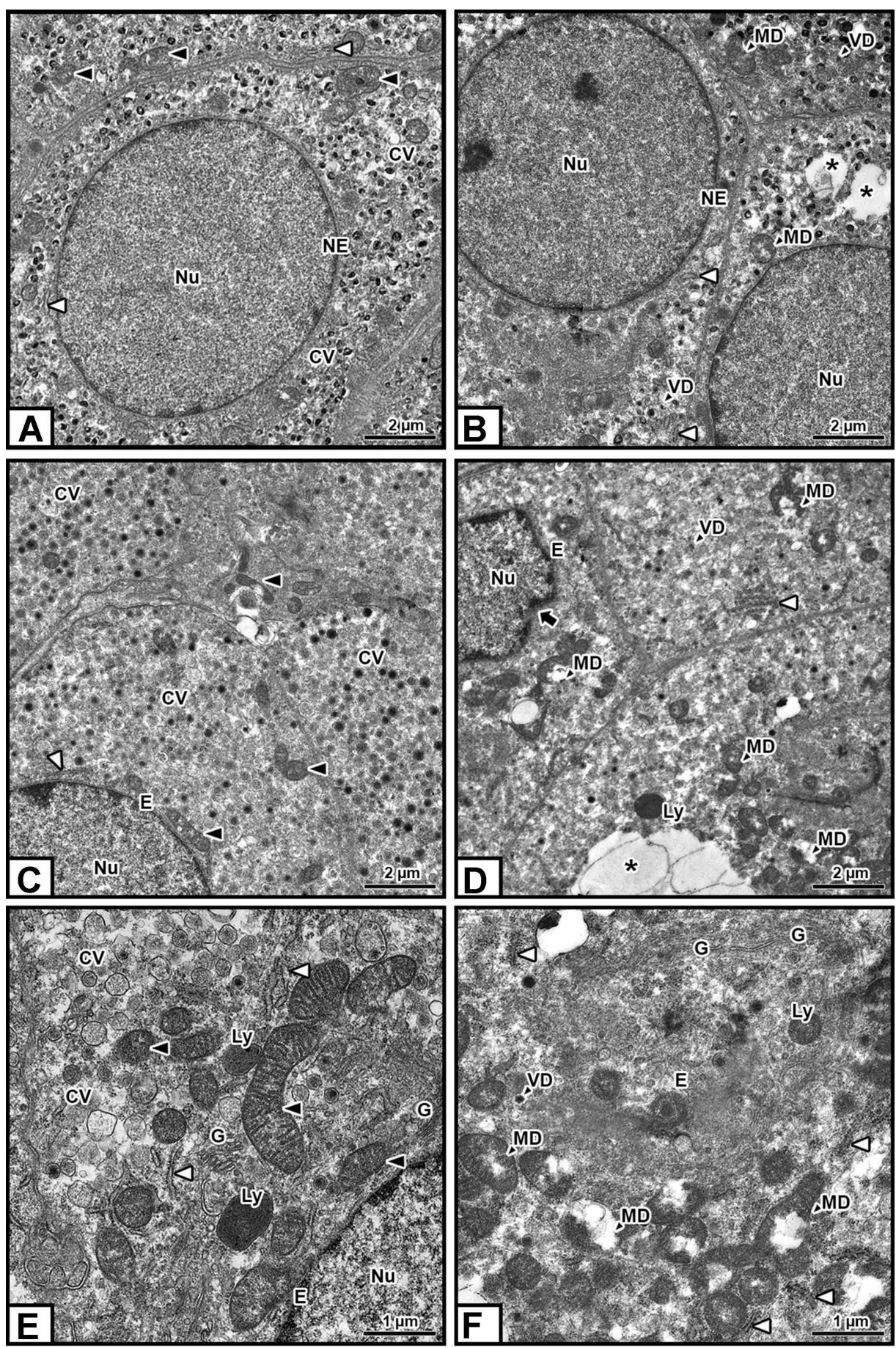

Ultrastructural study of the adrenocorticomedullary interaction. Close contacts between cortical cells and chromaffin cells in the control adrenal cortex were demonstrated. The control ZG cells contained mitochondria, with tubular cristae, and lipid droplets. ZG cells extended filopodia to contact chromaffin cells (Fig. 3A). In the DM, the accumulation of collagen fibrils was observed between ZG and chromaffin cells (Fig. 3B). The control ZF cells contained mitochondria, with vesicular cristae, and large-sized lipid droplets. The chromaffin cells consisted of chromaffin vesicles, mitochondria, and rER in the cytoplasm (Fig. 3C). In the DM model group, filopodia from ZF cells and processes of chromaffin cells were observed. Most chromaffin vesicles appeared to

Fig. 2. Transmission election micrographs of norepinephrinesecreting cells (NE) (2A-B) and epinephrine-secreting cells (E) (2C$\mathrm{F}$ ) in adrenal medulla of the control (2A, 2C, 2E) and short-term DM model groups $(2 \mathrm{~B}, 2 \mathrm{D}, 2 \mathrm{~F})$. Nucleus $(\mathrm{Nu})$, an invagination of nuclear membrane (a black arrow), mitochondria (black arrowheads), disrupted cristae of mitochondria (MD), rER (white arrowheads), chromaffin vesicles (CV), degenerated chromaffin vesicles (VD), lysosome (Ly), Golgi apparatus $(G)$, loss of cell organelles (black asterisks). 
be disrupted. Wider intercellular spaces and collagen fibril depositions were observed between cells in the DM (Fig. 3D). The control ZR cells contained mitochondria, with tubulovesicular cristae, lipofuscin granules, and filopodia.
The chromaffin cells contained numerous chromaffin vesicles and mitochondria (Fig. 3E). In the DM, collagen fibril accumulation was observed in the intercellular spaces. The filopodia of ZR cells were larger in the DM (Fig. 3F).
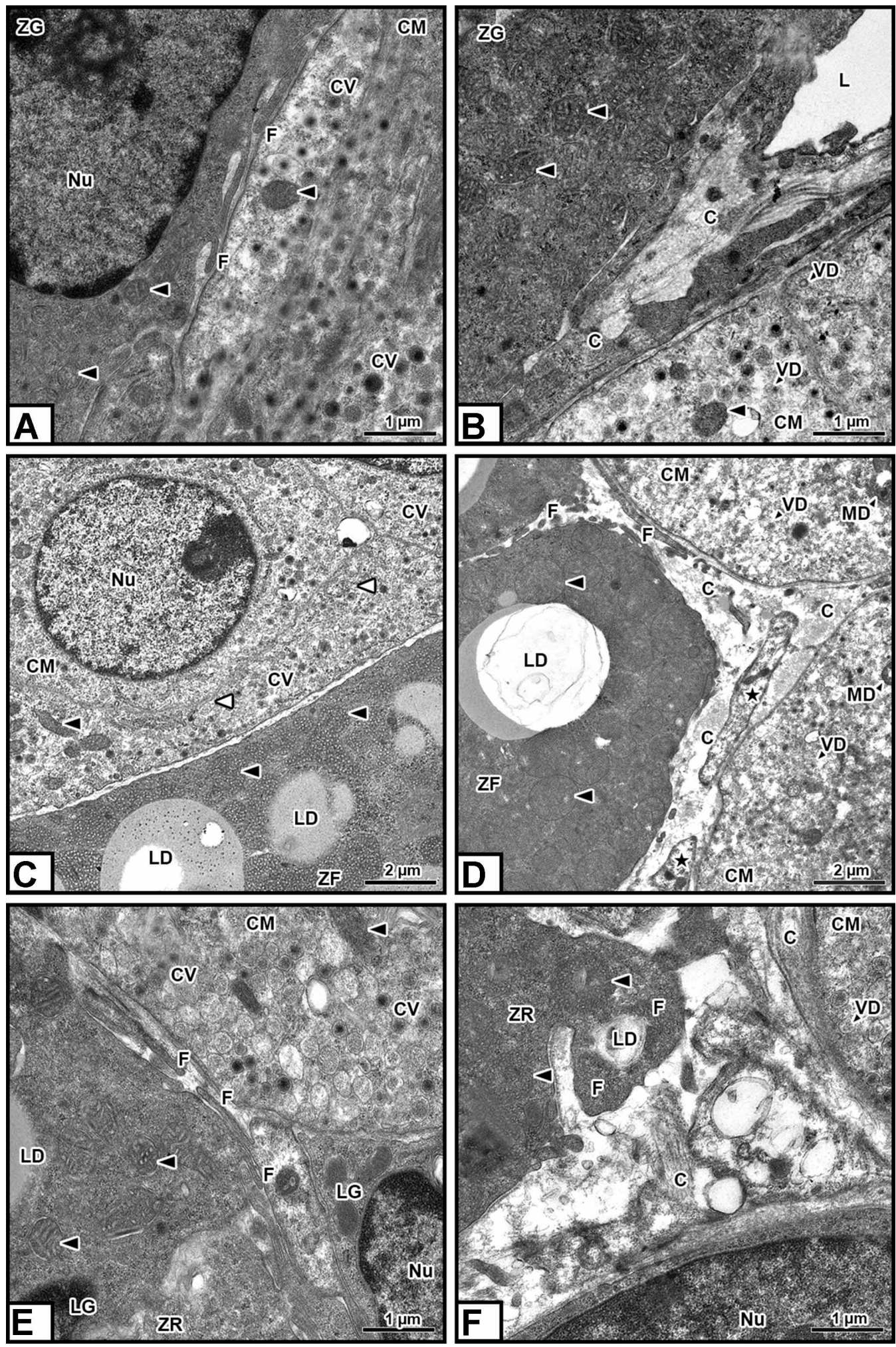

Fig. 3. Transmission electron micrographs of adrenocorticomedullary cells in the zona glomerulosa (ZG) (3A-B), zona fasciculata (ZF) (3C$\mathrm{D})$, and zona reticularis (ZR) (3E-F) of the control $(3 \mathrm{~A}, 3 \mathrm{C}, 3 \mathrm{E})$ and shortterm DM model groups (3B, 3D, 3F). Chromaffin cells $(\mathrm{CM})$, chromaffin vesicles $(\mathrm{CV})$, degenerated chromaffin vesicles (VD), nucleus $(\mathrm{Nu})$, mitochondria (black arrowheads), destructed mitochondria (MD), lipofuscin granules (LG), lipid droplets (LD), rER (white arrowheads), processes of chromaffin cells (black stars), filopodia (F), collagen fibrils (C), lumen of capillary (L). 


\section{DISCUSSION}

After STZ-induction, rats presented hyperglycemia, glucosuria, and unexplained weight loss, similar to previous studies (Lanlua et al., 2007; Sricharoenvej et al.; Niyomchan et al.; Lanlua et al., 2019).

In the adrenal cortex, during the early stages of DM model in rats and type $1 \mathrm{DM}$ patients, increased numbers of angiotensin receptorsand concentrations of plasma AII have been reported in ZG cells (Hollenber et al., 2004). Aldosterone precursors and enzymes in sER and mitochondria increase in diabetic ZG (Mazzocchi et al., 1986). Therefore, aldosterone synthesis increases. Increased corticotrophin releasing hormone mRNA in DM has been detected, resulting in high plasma ACTH (Chan et al., 2001). Thus, plasma aldosterone concentrations increase. However, plasma aldosterone levels were found to decrease 4 weeks after STZ injection (El-Feky et al., 2010). The cell sizes ofproximal convoluted tubule increase, the basement membrane thickens, and lipid peroxidation occurs, resulted in decreased glucose reabsorption (Lanlua et al., 2007). Altogether, high levels of aldosterone synthesis together with increased water loss, promote aldosterone production. The ultrastructure of ZG cells in DM model animals revealed distended mitochondria and sER.Lipid droplets is a precursor of aldosterone synthesis (El-Feky et al.). Therefore, high levels of aldosterone can result in lipid droplet reductions. The ZF cells in DM resembled the ultrastructure of ZG cells. ZF cells were shown large mitochondria and sER reduced lipid droplets. As a result, high cortisol levels stimulate gluconeogenesis (Molina, 2018). ZR cells showed similar characteristics to ZG cells. ZR cells exhibited extended mitochondria and sER but decreased lipid droplets. However, the sER enzyme involved in androgen synthesis, 17, 20-lase, decreases, resulting in low plasma androgen levels (BarrettConnor).

In the cortical cells, membrane disruptions were observed, including the loss of gap junctions and increased numbers of filopodia associated with the cortical cells. Hyperglycemia increases reactive oxygen species (ROS) formation, which induces lipid peroxidation (Bizzozero et al., 2001). Lipid peroxidation refers to the oxidative degradation of lipids in cell membranes. Moreover, the hyperphosphorylation of connexin-43 occurs during DM, causing gap junction closure and a decrease in the number of gap junctions in diabetic heart (Lin et al., 2006). The filopodia are associated with the gap junction (Mattilla \& Lappalainen, 2008). Therefore, large numbers of filopodia may serve as an additional cellular communication system. In addition, a decrease in the diameter of cortical capillaries has been observed in DM animals (Sricharoenvej et al.). Cortical cells became likely extended their filopodia to directly contact fenestrated capillaries. In addition, the phosphorylation of protein kinase $\mathrm{C}$ sigma induces nuclear lamina disassembly of rat heart cells (Brodie \& Blumberg, 2003). The number of mitochondria increases, especially in the perinuclear region. So that, the invaginations of the nuclear membrane occur. In the ZR, androgens expressed increase chromogranin A expression, which may be associated with the disruptions in chromaffin vesicles in DM (Haase et al.). Hyperglycemia causes the increased activity of the lipoprotein lipase, which results in altered biological membrane properties. Moreover, advanced glycation end products increase in the mitochondria. Consequently, the loss of membrane permeability for mitochondria, rER, and the Golgi apparatus causes intracellular organelles to swell (Crompton, 1999). Furthermore, high levels of ROS alter the phospholipid composition of the mitochondrial inner membrane, disrupting the mitochondrial cristae (De Fronzo et al., 2010). Damaged intracellular organelles are digested by the lysosomal hydrolases (Powers et al., 2005). Additionally, the sympathetic ganglion cells in DM did not show morphological changes (Noorafshan et al., 2005).

Structural modifications to the adrenal gland occur in diabetic rats that may contribute to pathological changes. These changes can involve in the hormonal syntheses and releases. The findings will be useful for clarifying the pathology of the adrenal gland during the progression of short-term DM.

\section{ACKNOWLEDGEMENTS}

This research was supported by Chalermphrakiat Grant, Faculty of Medicine Siriraj Hospital, Mahidol University, Thailand.

BAIMAI， S.; BHANICHKUL， P.; LANLUA， P.; NIYOMCHAN, A. \& SRICHAROENVEJ, S. Modificaciones de la ultraestructura de la glándula suprarrenal en ratas modelo diabéticas inducidas por estreptozotocina. Int. J. Morphol., 39(1):109-115, 2021.

RESUMEN: La glándula suprarrenal se ha asociado con el desarrollo de síntomas clásicos en la diabetes mellitus (DM), que incluyen poliuria intensiva e hiperglucemia. Durante la DM, hay cambios hormonales en la glándula suprarrenal. Los cambios ultraestructurales de las células adrenocorticales y de la médula suprarrenal y sus efectos sobre la interacción adrenocorticomedular no se han investigado completamente. Este estudio evaluó las células adrenocorticales y de la médula suprarrenal y las interacciones adrenocorticomedulares a niveles ultraestructurales en un modelo 
de DM inducida por estreptozotocina, utilizando microscopía electrónica de transmisión. Se dividieron quince ratas macho SpragueDawley en grupos de modelo diabético $(\mathrm{n}=10)$ y de control $(\mathrm{n}=$ 5). Las ratas se sacrificaron cuatro semanas después de la inducción. Se encontró que los núcleos de algunas células corticales diabéticas tenían una forma irregular. En el citoplasma, se observó un mayor número de mitocondrias y retículo endoplásmico liso dilatado. Sin embargo, las gotitas de lípidos disminuyeron en los animales modelo DM. Los filopodios de las células corticales diabéticas se extendieron para entrar en contacto con el capilar fenestrado y otras células corticales y también se observaron pérdidas de uniones gap. Las alteraciones de las células cromafines diabéticas dieron como resultado apariencias similares, que consistían en núcleos de forma irregular, mitocondrias inflamadas, retículo endoplásmico rugoso distendido y vesículas cromafines rotas. El examen de las interacciones adrenocorticomedulares mostró que las células cromafines corticales diabéticos se parecían a las de la médula. En el grupo del modelo de DM, se observaron depósitos de fibrillas de colágeno entre las células suprarrenales, especialmente cerca de las interacciones celulares. Los filopodios de las células corticales diabéticas eran más grandes que los observados para las interacciones adrenocorticomedulares diabéticas y la corteza suprarrenal. Estas modificaciones ultraestructurales de la glándula suprarrenal contribuyen al conocimiento básico para las investigaciones referente al deterioro de la glándula en el diagnóstico temprano de pacientes con DM.

PALABRAS CLAVE: Glándula suprarrenal; Interacciones adrenocorticomedulares; Estreptozotocina; Diabetes mellitus; Rata.

\section{REFERENCES}

Barrett-Connor, E. Lower endogenous androgen levels and dyslipidemia in men with non-insulin-dependent diabetes mellitus. Ann. Intern. Med., 117(10):807-11, 1992.

Bizzozero, O. A.; Bixler, H. A.; Davis, J. D.; Espinosa, A. \& Messier, A. M. Chemical deacylation reduces the adhesive properties of proteolipid protein and leads to decompaction of the myelin sheath. J. Neurochem., 76(4):1129-41, 2001.

Brodie, C. \& Blumberg, P. M. Regulation of cell apoptosis by protein kinase c d. Apoptosis, 8:19-27, 2003.

Carson, K. A.; Hanker, J. S. \& Kirshner, N. The adrenal medulla of the diabetic mouse (C57BL/KsJ, db/db): biochemical and morphological changes. Comp. Biochem. Physiol. A Comp. Physiol., 72(2):279-85, 1982.

Chan, O.; Chan, S.; Inouye, K.; Vranic, M. \& Matthews, S. G. Molecular regulation of the hypothalamo-pituitary-adrenal axis in streptozotocininduced diabetes: effects of insulin treatment. Endocrinology, 142(11):4872-9, 2001.

Crompton, M. The mitochondrial permeability transition pore and its role in cell death. Biochem. J., 341(Pt. 2):233-49, 1999.

De Fronzo, R. A.; Ferrannini, E.; Keen, H. \& Zimmet, P. International Textbook of Diabetes Mellitus. 4th ed. London, Wiley-Blackwell, 2010.

El-Feky, H.; Salah, A.; Hussein, Y. \& Sabry, M. Histological study of the effect of induced diabetes on the zona glomerulosa of the adrenal cortex of adult male albino rat. Egypt. J. Histol., 33(1):17-22, 2010.

Fauci, A. S.; Braunwald, E.; Kasper, D. L.; Hauser, S. L.; Longo, D. L.; Jameson, J. L. \& Loscalzo, J. Harrison's Manual of Medicine. 17th ed. New York, McGraw-Hill, 2009.
Haase, M.; Willenberg, H. S. \& Bornstein, S. R. Update on the corticomedullary interaction in the adrenal gland. Endocr. Dev., 20:2837,2011 .

Hollenberg, N. K.; Stevanovic, R.; Agarwal, A.; Lansang, M. C.; Price, D. A.; Laffel, L. M. B.; Williams, G. H. \& Fisher, N. D. L. Plasma aldosterone concentration in the patient with diabetes mellitus. Kidney Int., 65(4):1435-9, 2004.

Kierszenbaum, A. L. \& Tres, L. T. Histology and Cell Biology. $4^{\text {th }}$ ed. Philadelphia, Elsevier Saunders, 2016.

Lanlua, P.; Prommahom, A. \& Sricharoenvej, S. Increased number of activated microglia in rat spinal cord during early stage of diabetic induction. Folia Morphol. (Warsz.), 2019. DOI: https://www.doi.org/ 10.5603/FM.a2019.0136, 2019

Lanlua, P.; Tongpob, Y.; Niyomchan, A.; Phoungpetchara, A. \& Srichareonvej, S.Impairment of renal morphology in short-termed streptozotocin-induced diabetic rats. Siriraj Med. J., 59:149-51, 2007.

Lin, H.; Ogawa, K.; Imanaga, I. \& Tribulova, N. Remodeling of connexin 43 in the diabetic rat heart. Mol. Cell. Biochem., 290(1-2):69-78, 2006.

Mattilla, P. K. \& Lappalainen, P. Filopodia: molecular architecture and cellular functions. Nat. Rev. Mol. Cell Biol., 9(6):446-54, 2008.

Mazzocchi, G.; Malendowicz, L. K.; Rebuffat, P.; Robba, C.; Gottardo, G. $\&$ Nussdorfer, G. G. Short- and long-term effects of ACTH on the adrenal zona glomerulosa of the rat. A coupled stereological and enzymological study. Cell Tissue Res., 243(2):303-10, 1986.

Molina, P. E. Endocrine Physiology. $5^{\text {th }}$ ed. New York, McGraw-Hill Education, 2018.

Niyomchan, A.; Sricharoenvej, S.; Lanlua, P. \& Baimai, S. Cerebellar synaptopathy in streptozotocin-induced diabetic rats. Int. J. Morphol., 37(1):28-35, 2019.

Noorafshan, A.; Azizi, M.; Aliabadi, S. \& Karbeley-Dorst, S. Stereological study on the neurons of superior cervical sympathetic ganglion in diabetic rats. Iran. J. Med. Sci., 30(1):24-7, 2005.

Powers, S. K.; Kavazis, A. N. \& DeRuisseau, K. C. Mechanisms of disuse muscle atrophy: role of oxidative stress. Am. J. Physiol. Regul. Integr. Comp. Physiol., 288(2):R337-44, 2005.

Rebuffat, P.; Belloni, A. S.; Malendowicz, L. K.; Mazzocchi, G.; Meneghelli, V. \& Nussdorfer, G. G. Effects of streptozotocin-induced experimental diabetes on the morphology and function of the zona fasciculata of rat adrenal cortex. Virchows Arch. B Cell. Pathol. Incl. Mol. Pathol., 56(1):13-9, 1988.

Sricharoenvej, S.; Boonprasop, S.; Lanlua, P.; Piyawinijwong, S. \& Niyomchan, A. Morphological and microvascular changes of the adrenal glands in streptozotocin-induced long-term diabetic rats. Ital. J. Anat. Embryol., 114(1):1-10, 2009.

\section{Corresponding author:}

SirinushSricharoenvej, Ph.D.

Department of Anatomy

Faculty of Medicine Siriraj Hospital

Mahidol University

Bangkok 10700

THAILAND

Email: sirinush.sri@mahidol.ac.th

Received: 11-09-2020

Accepted: 01-10-2020 